\title{
Probiotic Characterization of Lactobacilli and Yeast Strains Isolated from Whey Beverage and Therapeutic Potential of Lactobacillus Yoghurt in Murine Giardiasis
}

\author{
Geeta Shukla*1 , Gatha Sharma and Nisha Goyal \\ ${ }^{1}$ Department of Microbiology, Panjab University, Chandigarh-160014, India. \\ *Corresponding Author: \\ Dr (Mrs) Geeta Shukla \\ Assistant Professor \\ Department of Microbiology \\ Panjab University \\ Chandigarh- 160014 \\ Tel: +91(172) 2534146 \\ Fax: +91 (172) 2541770 \\ Email: geeta_shukla@pu.ac.in
}

Received: 27 November 2009; | Revised: 3 April 2010; | Accepted: 10 April 2010

\begin{abstract}
In the present study, an attempt has been made to assess the probiotic characteristics of lactobacilli and yeast strains isolated from whey beverage under conditions simulating the in vivo stresses encountered in the gastrointestinal tract i.e. acid, alkaline, proteolytic enzymes and bile stress. The therapeutic potential of probiotics Lactobacillus casei or Lactobacillus yoghurt was assessed in Giardia infected mice. All the isolated strains well tolerated the gastrointestinal stresses. It was found that probiotic supplementation of either L. casei or L. yoghurt, one day after Giardia infection, reduced the severity of infection compared to Giardia infected mice. Pathophysiologically, the morphological and cellular changes in the small intestine were least in probiotic treated mice compared to severely inflamed, oedematous, vacuolated epithelial cells in Giardia infected mice. It can be concluded that L. yoghurt possessed better probiotic properties and has the potential to reduce the severity of Giardia infection in mice.
\end{abstract}

Keywords: Giardiasis; Probiotic; Therapeutic; Microbial Interference Therapy (MIT).

\section{Introduction}

Giardia lamblia (synonyms: Giardia intestinalis or Giardia duodenalis) is the flagellated intestinal protozoan which causes waterborne diarrhea worldwide. Prevalence rate of giardiasis ranges from $20-30 \%$ in most developing countries and $2-7 \%$ in developed countries $[1,2,3]$. School children, malnourished individual, common variable immunodeficiency (CVID) patients, hypogammaglobulineamic patients and people with blood group-A are highly susceptible 
to giardiasis $[3,4]$. The clinical manifestations of Giardia infection are varied, with diarrhea being the predominant symptom, occurring in almost $90 \%$ of symptomatic patients.

Giardia is generally treated with antibiotics like nitroimidazoles and nitrofurans. However, clinical failures, occurrence of resistant strains, and side effects of anti-Giardia drugs [5, 6] have encouraged research on alternative biotherapeutic strategies such as plant extracts, products derived from bees and probiotics that are safe, inexpensive and effective in improving the cause of intestinal parasitosis [7]. Recently, Shukla et al. 2008 (8) have shown that probiotic L. casei MTCC 1423, modulates murine Giardia infection by minimizing or preventing the adherence of Giardia trophozoites to the mucosal surface, suggesting that probiotics offer a safe and effective mode to prevent / or treat the Giardia infection.

The term 'probiotic' is defined as 'microbial cell preparations or components of microbial cells that have a beneficial effect on the health and wellbeing [9]. Moreover, probiotics are emerging as an important new therapy for prevention and treatment of infectious diseases mainly gastrointestinal infections and are also known as microbial interference therapy (MIT). The main characteristics of a probiotic are resistance to digestion by enteric or pancreatic enzymes, gastric acid, bile, ability to prevent the adherence, establishment and replication of pathogens in the gastrointestinal tract [10]. However, the protective mechanism of a probiotic appears to be species and strain specific [11]. Thus, the present study was designed to study the probiotic characteristics of lactobacilli and yeast strains isolated from whey beverage vis a vis therapeutic potential of $L$. yoghurt on the establishment of murine giardiasis.

\section{Materials and Methods}

\subsection{Bacterial and Yeast strains}

Lactobacillus casei MTCC 1423, a standard lactic acid bacterial strain (LAB) was procured from Microbial Type Culture Collection (MTCC), Institute of Microbial Technology, Chandigarh, India. Lactobacillus choozit, Lactobacillus yoghurt, yeast strains P82, P84 and V84 isolated from whey beverage were kindly provided by Dr. Parampal Sahota, Punjab Agricultural University, Ludhiana, Punjab, India.

\subsection{Growth and maintenance of bacterial/yeast strains}

L. casei was grown in De Mann Rogosa Sharpe (MRS) broth at $37^{\circ} \mathrm{C}$ for $48 \mathrm{~h}$ and maintained on MRS agar plate by regular subculturing at an interval of 15 days. L. choozit and L. yoghurt were grown in Tomato Juice Broth (TJB) at $37^{\circ} \mathrm{C}$ for $24 \mathrm{~h}$ and maintained on Tomato Juice Agar (TJA) plates by regular subculturing. Yeast strains P82, P84 and V84 were grown in Glucose Yeast Extract (GYE) broth at $30^{\circ} \mathrm{C}$ in Biological Oxygen Demand (BOD) incubator for $30 \mathrm{~h}$ and maintained on GYE agar slants by regular subculturing.

\subsection{Phenotypic characterization of bacterial and yeast strains}

Morphological (Gram staining, colony morphology, motility) and biochemical characterization of the isolated strains was performed.

\subsection{Probiotic characteristics}

Isolated bacterial and yeast strains were screened for their probiotic characteristics under gastrointestinal stresses like bile, acid and enzyme tolerance. In addition, cholesterol assimilation of these strains in vitro was also assessed.

\subsection{Bile tolerance}

Bile tolerance of all the isolated strains was studied as per Gilliland et al. 1984 (12). Briefly, TJB supplemented with different concentrations of bile salts (sodium deoxycholate and sodium taurocholate; $0.3 \%, 1 \%$ and $2 \%$ ) was inoculated with $1 \%$ inoculum and incubated at $37^{\circ} \mathrm{C}$ for various time intervals (1h, $2 \mathrm{~h}$ and $3 \mathrm{~h}$ ). After each hour of incubation, samples were drawn, serially diluted, plated on TJA plates and incubated at $37^{\circ} \mathrm{C}$ for $24 \mathrm{~h}$. Growth on the plates indicated their tolerance to bile salts. The control comprised of TJB without bile salt. Yeast strains were also processed as above using GYE broth and GYE agar.

() 2010 by NWPII. All rights reserved. 


\subsection{Viability at $\mathrm{pH}$ extremes}

The isolated strains were screened for their survival and stability at $\mathrm{pH}$ extremes i.e. acidic $\mathrm{pH}$ 2.0 (homologous to stomach) and alkaline $\mathrm{pH} 8.0$ (homologous to intestinal tract).

\subsection{Acid tolerance}

TJB with different $\mathrm{pH}(2.0,6.3$, and 8.0) were prepared. TJB ( $\mathrm{pH} 2)$ was inoculated with lactobacilli culture (1\%) grown overnight in TJB (pH 6.7). Samples at $0 \mathrm{~h}$ and after $4 \mathrm{~h}$ of incubation were drawn, serially diluted, plated on TJA plates and incubated at $37^{\circ} \mathrm{C}$ for $24 \mathrm{~h}$.

\subsection{Alkaline tolerance}

After $4 \mathrm{~h}, 1 \%$ inoculum from TJB ( $\mathrm{pH} 2.0)$ was transferred to fresh TJB $(\mathrm{pH} \mathrm{8.0)}$ and the above steps were repeated (as for acid tolerance) to monitor the response of lactobacilli to alkaline $\mathrm{pH}$. Acid and alkaline tolerance of yeast strains were processed in the same way as above using GYE broth and GYE agar.

Growth of lactobacilli and yeast strains on the plates indicated their tolerance to extreme $\mathrm{pH}$.

\subsection{Enzyme tolerance}

Sensitivity of lactobacilli and yeast strains to oral and intestinal enzymes (lysozyme, trypsin and $\alpha$-amylase) was studied as per Nowroozi et al. 2004 (13). Lactobacilli and yeast strains were grown in the presence of various enzymes: lysozyme (22 IU mg $\left.\mathrm{ml}^{-1}\right)$, trypsin $\left(0.5 \mathrm{mg} \mathrm{ml}^{-1}\right)$ and $\alpha$-amylase $\left(220 \mathrm{IU} \mathrm{mg}^{-1} \mathrm{ml}^{-1}\right)$ for $1 \mathrm{~h}$ at $30^{\circ} \mathrm{C}$, thereafter transferred to $37{ }^{\circ} \mathrm{C}$ and was incubated for another $1 \mathrm{~h}$. Both optical density (OD $600 \mathrm{~nm}$ ) and colony forming units (CFU) were recorded at $0 \mathrm{~h}$ and after $2 \mathrm{~h}$ of incubation. A control (without enzyme) was also processed.

\subsection{Cholesterol assimilation from culture media}

Assay was performed as per Liong \& Shah, 2005 (14). Briefly, freshly prepared TJB was supplemented with $0.3 \%$ oxgall (bile salt) and cholesterol $\left(100 \mu \mathrm{g} \mathrm{ml}^{-1}\right)$ and was inoculated with $1 \%$ of respective cultures, incubated at $37^{\circ} \mathrm{C}$ for 20 h. After incubation, cultures were centrifuged and unutilized cholesterol was estimated in the supernatant by the modified method of Zlatkis et al.1953 (15). Optical density $\left(\mathrm{OD}_{540 \mathrm{~nm}}\right)$ was measured and results were expressed as follows:

$\%$ cholesterol assimilated $=\underline{(\mathrm{a}-\mathrm{b})} \times 100$ a $\mathrm{a}=$ initial concentration of cholesterol in the medium $(\mu \mathrm{g})$.

$$
\begin{aligned}
\mathrm{b}= & \text { final concentration of cholesterol left } \\
& \text { in the medium after } 20 \text { hours of } \\
& \text { incubation }(\mu \mathrm{g})
\end{aligned}
$$

\subsection{In vivo studies}

After assessing the probiotic characteristics of the isolated strains, therapeutic potential of $L$. casei and L. yoghurt in Giardia infected mice was assessed.

\subsection{Parasite}

Giardia lamblia trophozoites (Portland strain I ) were grown auxenically in TYI-S-33 medium supplemented with antibiotic solution and $\mathrm{pH}$ was adjusted to 6.9 , before sterilization with $0.22 \mu \mathrm{m}$ seitz filter. Actively growing trophozoites (48-72 $\mathrm{h}$ old culture) were sedimented by chilling the tubes in ice for $15 \mathrm{~min}$ followed by centrifugation at $2000 \mathrm{rpm}$ for $15 \mathrm{~min}$. Trophozoites were suspended in phosphate buffer saline (PBS- 7.2) to a final concentration of $1 \times 10^{6}$ trophozoites / 0.1 $\mathrm{ml}$.

\subsection{Bacterial strains, preparation and inoculation}

For experimental inoculation, $18 \mathrm{~h}$ old cultures of $L$. casei and $L$. yoghurt were centrifuged at $8000 \mathrm{rpm}$ for $10 \mathrm{~min}$ and pellets were washed with PBS- 7.2. Finally, suspended in PBS-7.2 to contain $1 \times 10^{9}$ lactobacilli / $0.1 \mathrm{ml}$ and were fed intra oesophageally via catheter [8].

\subsection{Animals}

BALB/c mice aged $5-6$ weeks old (18-20 gm) obtained from Central Animal House, Panjab University, Chandigarh, India, were housed under standard conditions of light and dark cycle with free access to feed (Ashirwad Industries Pvt. Ltd., Ropar, India) and water ad libitum. Both water and feed were monitored for any bacterial or parasitic contamination by Gram's staining and Lugol's iodine staining techniques before 
providing to animals [16]. Animals were also screened for any protozoal infection via stool examination for three consecutive days [8]. Mice free from parasitic infections were used. Care and use of animals were in accordance with the guidelines of the institutional ethical committee.

\subsection{Experimental design}

To carry out the study animals were divided into 4 groups, each containing 15 animals. Group I (Control): These animals were fed with a single dose of PBS -7.2 via orogastric gavages daily for 30 days. Group II (Giardia-infected): These mice were challenged orally with a single dose of $1 \times 10^{6}$ Giardia trophozoites. Group III (GiardiaL.casei): These animals were challenged orally with a single dose of $1 \times 10^{6}$ Giardia trophozoites. A day after Giardia challenge, mice were fed orally with a single dose of L. casei $\left(1 \times 10^{9}\right)$. The probiotic treatment was continued for 30 days. Group IV (Giardia-L. yoghurt): Animals belonging to this group were challenged orally with a single dose of $1 \times 10^{6}$ Giardia trophozoites. A day after Giardia challenge, a single dose of $L$. yoghurt $\left(1 \times 10^{9} \mathrm{cfu} / 0.1 \mathrm{ml}\right)$ was administered daily for 30 days.

\subsection{Follow up of animals}

After respective treatments in different groups, Giardia cysts counts, lactobacilli counts, trophozoites counts and pathological changes in the small intestine were studied.

\subsection{Enumeration of Giardia cysts in faeces}

Cysts in the faecal samples of mice were enumerated as per Shukla et al. 2008 (8). Briefly, one gram of freshly passed fecal sample was dissolved in $10 \mathrm{ml}$ of normal saline, homogenized using pestle and mortar. Cysts stained with iodine were counted on every third day using hemocytometer and were expressed as cysts $\mathrm{ml}^{-1}$.

\subsection{Enumeration of lactobacilli in faeces}

To confirm whether the lactobacilli species were able to survive the stress within the gastrointestinal tract, freshly voided faecal samples from each group of mice were homogenized in normal saline and serially diluted, plated on MRS agar, incubated at $37^{\circ} \mathrm{C}$ for $24-$ 48hrs and colony forming units (cfu) were counted [8].

\subsection{Enumeration of Giardia trophozoites in the small intestine (jejunum)}

The trophozoites were counted in the intestinal fluid of animals belonging to groups II, III, IV respectively [17]. Mice were sacrificed and the proximal $10 \mathrm{~cm}$ section, mainly the jejunum was removed and placed in $5 \mathrm{ml}$ of ice chilled saline. The small intestine sections were minced, kept for 15-20 minutes in ice chilled saline and trophozoites were counted using haemocytometer.

\subsection{Histopathological studies}

Mice were sacrificed by cervical dislocation and upper part (jejunum) of the small intestine was removed aseptically, fixed in $10 \%$ buffered formalin, processed, stained with haematoxylin and eosin and were examined under the light microscope.

\subsection{Statistical analysis}

The inter group variation was assessed by one way analysis of variance (ANOVA). Statistical significance of the result was calculated.

\section{Results and Discussion}

The emergence of antibiotic resistant bacteria and natural ways of suppressing the growth of pathogens has contributed to the concept of 'Probiotics'. Probiotic bacteria not only compete and suppress 'unhealthy fermentation' in human intestine but also have a number of health benefits [18]. Moreover, the health benefits of probiotic vary with the species and strains of probiotics. Hence, it becomes pertinent to isolate and identify probiotics that have disease specific health benefits [19]. Therefore, the present study was designed to delineate the probiotic characteristics of the bacterial and yeast strains isolated from whey beverage vis a vis therapeutic potential in murine giardiasis.

\subsection{Identification of different bacterial and yeast isolates}


The different phenotypic characteristics such as colony morphology, Gram reaction, catalase, motility, and sugar fermentation of different bacterial and yeast isolates (from whey beverage) were studied. All lactic acid bacteria were Gram positive rods, catalase negative, non motile but had different sugar fermentation ability (Table1). Similarly, all yeast strains also had different sugar fermentation ability (Table 2).

Table 1: Morphological characteristics and sugar fermentation by lactobacilli strains. $(+)=$ utilization of sugars; $(-)=$ Non utilization of sugars.

\begin{tabular}{|l|l|l|l|}
\hline Characteristics & Lactobacillus casei & Lactobacillus Choozit & Lactobacillus Yoghurt \\
\hline Gram reaction & $\begin{array}{l}\text { Gram +ve, thin bacilli in } \\
\text { chains }\end{array}$ & $\begin{array}{l}\text { Gram +ve, thin, long and } \\
\text { short rods }\end{array}$ & Gram +ve, thin short rods \\
\hline $\begin{array}{l}\text { Colony } \\
\text { characteristics }\end{array}$ & $\begin{array}{l}\text { White, pin head, round, } \\
\text { entire margins, smooth } \\
\text { texture, slightly elevated, } \\
\text { non lustrous. }\end{array}$ & $\begin{array}{l}\text { White, pin head, round, } \\
\text { irregular margins, } \\
\text { smooth texture, flat, non } \\
\text { lustrous. }\end{array}$ & $\begin{array}{l}\text { Creamy white, translucent, } \\
\text { pin head, round, entire } \\
\text { margins, smooth texture, flat, } \\
\text { non lustrous, glistening. }\end{array}$ \\
\hline Catalase & - & - & - \\
\hline Motility & - & - & - \\
\hline $\begin{array}{l}\text { Sugar } \\
\text { utilization }\end{array}$ & + & + & \\
\hline Glucose & + & + & + \\
\hline Arabinose & + & + & + \\
\hline Cellobiose & + & + & + \\
\hline Lactose & + & + & + \\
\hline Maltose & + & + & + \\
\hline Mannose & + & + & + \\
\hline Mannitol & + & + & + \\
\hline Mellibiose & + & + & + \\
\hline Raffinose & + & + & + \\
\hline Rhamnose & + & + & + \\
\hline Sorbitol & + & + & + \\
\hline Sucrose & + & + & + \\
\hline Xylose & + & + & + \\
\hline Galactose & + & + & + \\
\hline Fructose & + & + & + \\
\hline
\end{tabular}

\subsection{Bile tolerance}

Gastrointestinal systems have varying concentrations of bile ranging $0.5 \%$ to $2.5 \%$ in the first hour of digestion and the levels may decrease further in subsequent hours. Moreover, tolerance to bile salts is considered to be a main prerequisite for growth, colonization and metabolic activity of bacteria in the host's gut [14]. Therefore, it is generally included in the selection criteria of potential probiotic. In the present study it was observed that all the isolated strains survived and tolerated bile salts $(0.3 \%)$ quite effectively. But a marginal decrease in the viability of all the isolated strains was found at $0.3 \%$ and $1 \%$ bile salt concentrations for different time intervals (Figure 1 and 2). However, at higher concentration (2\%) bile tolerance of all the strains decreased significantly ( $<<0.05$, Figure 3$)$. The difference in the level of bile tolerance of strains in the present study may probably be due to differences in their ability to grow and colonize the intestinal tract and is in accordance with the earlier studies [20-22]. 
Table 2: Morphological characteristics and sugar fermentation by yeast strains. $(+)=$ utilization of sugars $(-)=$ Non utilization of sugars

\begin{tabular}{|l|c|l|c|}
\hline Characteristics & Yeast P82 & Yeast P84 & Yeast V84 \\
\hline $\begin{array}{l}\text { Colony } \\
\text { characteristics }\end{array}$ & $\begin{array}{l}\text { Pure white, pin head, round, } \\
\text { entire margins, smoth } \\
\text { texture, elevated, shiny. }\end{array}$ & $\begin{array}{l}\text { Pure white, pin point, round, } \\
\text { entire margins, smooth } \\
\text { texture, elevated, shiny. }\end{array}$ & $\begin{array}{l}\text { Creamy white, pin head, } \\
\text { round, entire margins, } \\
\text { smooth texture, elevated, } \\
\text { shiny. }\end{array}$ \\
\hline $\begin{array}{l}\text { Sugar } \\
\text { utilization }\end{array}$ & & & \\
\hline Glucose & - & - & + \\
\hline Arabinose & - & - & - \\
\hline Cellobiose & - & - & - \\
\hline Lactose & - & + & + \\
\hline Maltose & - & + & + \\
\hline Mannose & + & - & - \\
\hline Mannitol & + & + & - \\
\hline Mellibiose & - & + & - \\
\hline Raffinose & + & - & + \\
\hline Rhamnose & + & - & + \\
\hline Sorbitol & - & + & - \\
\hline Sucrose & + & - & + \\
\hline Xylose & - & + & + \\
\hline Galactose & - & + & + \\
\hline Fructose & + & & - \\
\hline
\end{tabular}

Table 3: Viability of lactobacilli and yeast strains at extreme $\mathrm{pH}$ values.

\begin{tabular}{|l|lc|ll|}
\hline Organism & \multicolumn{2}{|c|}{$\mathbf{2 . 0}$} & \multicolumn{2}{c|}{$\mathbf{8 . 0}$} \\
\hline & 0 hour & 4hours & 0 hour & 4hours \\
\hline L.casei & $8.20 \pm 0.18$ & $7.76 \pm 0.20$ & $6.96 \pm 1.15$ & $5.97 \pm 0.56$ \\
\hline L.yoghurt & $7.72 \pm 0.90$ & $7.14 \pm 0.15$ & $6.61 \pm 0.91$ & $5.65 \pm 2.15$ \\
\hline L.choozit & $7.530 \pm 2.15$ & $6.23 \pm 0.40$ & $5.74 \pm 1.25$ & $4.87 \pm 1.55$ \\
\hline P82 & $7.843 \pm 1.26$ & $7.1 \pm 1.05$ & $6.877 \pm 0.66$ & $5.56 \pm 0.88$ \\
\hline P84 & $7.732 \pm 0.99$ & $6.84 \pm 0.25$ & $6.23 \pm 0.43$ & $5.74 \pm 0.01$ \\
\hline V84 & $7.515 \pm 1.16$ & $6.66 \pm 0.31$ & $5.93 \pm 0.31$ & $5.48 \pm 0.75$ \\
\hline
\end{tabular}

Values are expressed as $\log _{10} \mathrm{cfu} / \mathrm{ml}$.

\subsection{Viability at extreme pH}

Beneficial aspects of probiotic strains can be expected only when they are able to survive passage through the human stomach, digestive system and colonize the human gut. Of all the strains, L. choozit was most susceptible to acidic and alkaline $\mathrm{pH}$ while L.casei appeared to be resistant to both $\mathrm{pH}$ extremes (Table 3 ). It is reported that some probiotic strains are more tolerant to acidic conditions than others either due to high cytoplasmic buffering capacity ( $\mathrm{pH} \mathrm{3.72-}$ 7.74) or membrane ATPases, that in turn may resist changes in the cytoplasmic $\mathrm{pH}$ and gain stability under acidic conditions [23,24]. 


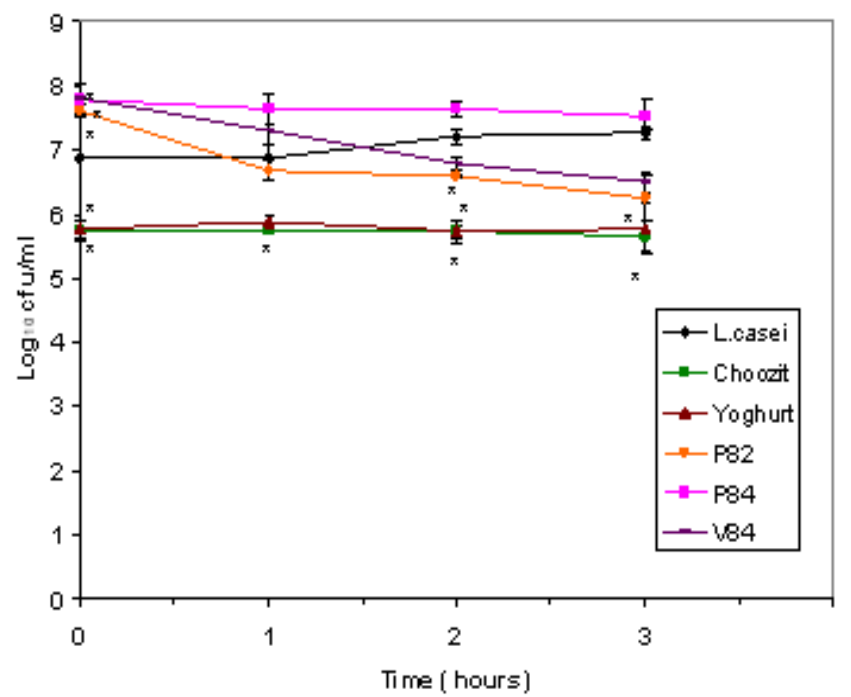

Figure 1: Survivability of lactobacilli and yeast strains in culture medium containing $0.3 \%$ bile salts. Values are Mean \pm SD. $* \mathrm{p}<0.05 \mathrm{v} / \mathrm{s}$ L. casei.

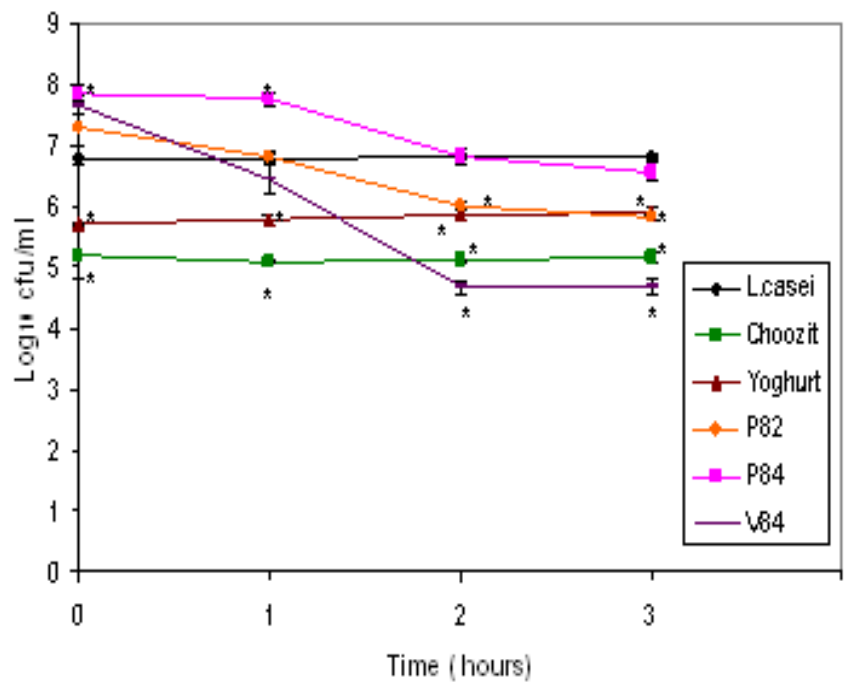

Figure 2: Survivability of lactobacilli and yeast strains in culture medium containing $1 \%$ bile salts. Values are Mean \pm SD. ${ }^{*} \mathrm{p}<0.05 \mathrm{v} / \mathrm{s}$ L. casei.

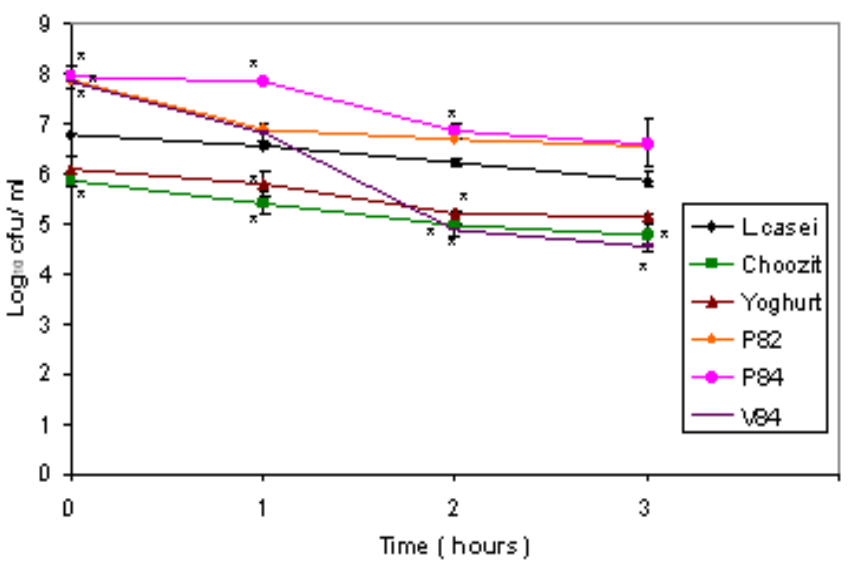

Figure 3: Survivability of lactobacilli and yeast strains in culture medium containing $2 \%$ bile salts. Values are Mean \pm SD. ${ }^{*} \mathrm{p}<0.05 \mathrm{v} / \mathrm{s}$ L.casei.

\subsection{Enzyme tolerance}

Bacteria and yeast used as probiotic adjuncts are commonly delivered in a food system and begin their journey to the lower intestinal tract via mouth. Therefore, these useful organisms should be resistant to the enzymes in the oral cavity (e.g. lysozyme) and in the intestine ( $\alpha$-amylase, lysozyme and trypsin). Interestingly, we found that all the strains grew equally well in the presence of either of these enzymes (Figure 4, 5, $6)$ and clearly suggests that these enzymes do not interfere with the survival and colonization of these organisms in the gut. This is the first study to report the enzyme tolerance of probiotic strains.

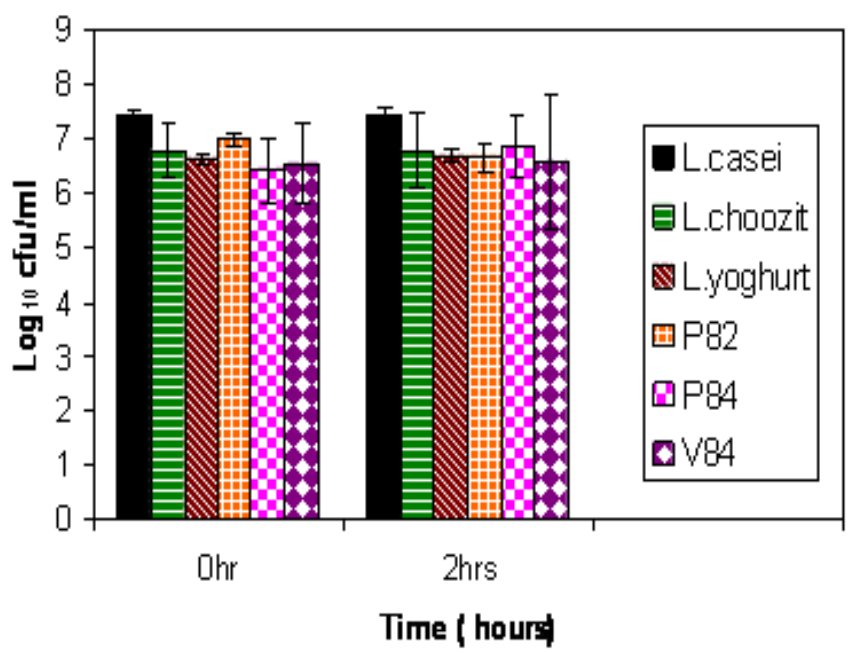

Figure 4: Survivability of lactobacilli and yeast strains in culture medium containing $\alpha$ - Amylase. Values are Mean \pm SD. ${ }^{*} \mathrm{p}<0.05 \mathrm{v} / \mathrm{s}$ L. casei. 


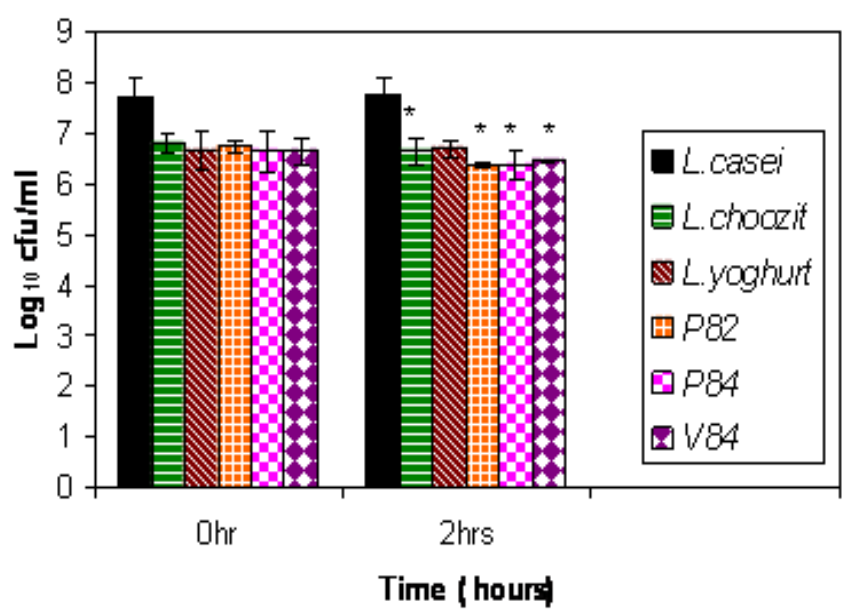

Figure 5: Survivability of lactobacilli and yeast strains in culture medium containing lysozyme. Values are Mean \pm SD. ${ }^{*} \mathrm{p}<0.05 \mathrm{v} / \mathrm{s}$ L. casei.

\subsection{Cholesterol Assimilation from culture media}

Various studies have strongly suggested that fermented milk could lower total cholesterol and low density lipoprotein (LDL) cholesterol, thus having a hypocholesterolemic effect $[25,26]$. These strains were also examined for their ability to assimilate cholesterol in vitro. The amount of cholesterol assimilation by these organisms revealed a wide variation (29 to 57\%) among the strains. Interestingly, L. yoghurt and P84 had significantly highest $(\mathrm{p}<0.05) \quad$ cholesterol assimilating ability while $L$. casei exhibited moderate, and L. choozit and V84 the least (Figure 7). The present observation corroborates with earlier studies where it has been reported that different strains of lactobacilli had different cholesterol assimilating ability and warrants further clinical studies [14, 20]. Therefore, it can be suggested that probiotic can also be used to treat hyper-cholesterolemic patients, thus reducing the heart attacks. The observed hypocholesterolemic effect of these strains may either be due to their ability to deconjugate bile acids into free acids which are excreted more rapidly (from the intestinal tract) than conjugated bile acids as the synthesis of new bile acids from cholesterol either reduces the total cholesterol concentration in the body or can be due to coprecipitation of cholesterol with bile acids at low $\mathrm{pH}[14,27]$.

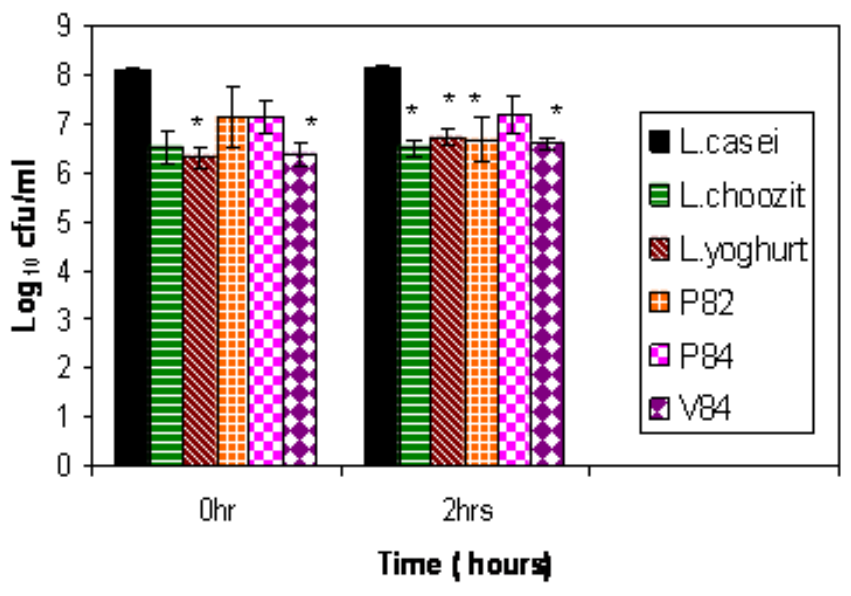

Figure 6: Survivability of lactobacilli and yeast strains in culture medium containing trypsin. Values are Mean \pm SD. $* \mathrm{p}<0.05 \mathrm{v} / \mathrm{s}$ L. casei.

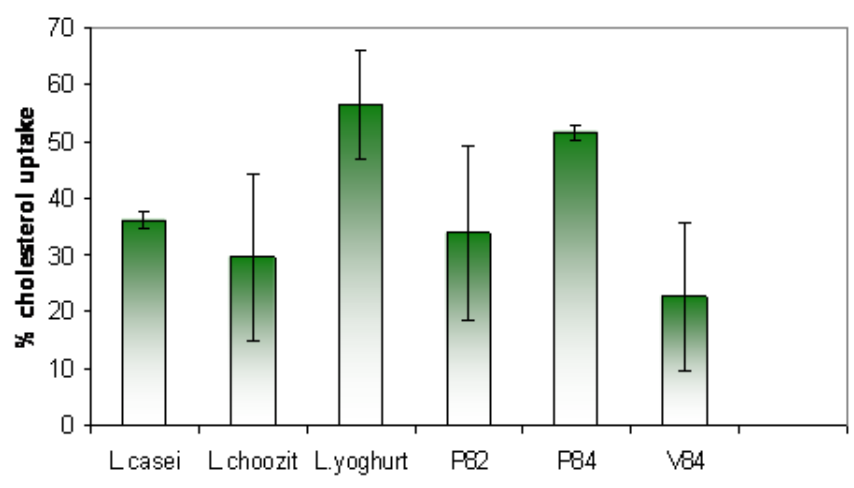

Figure 7: Percentage uptake of cholesterol by lactobacilli and yeast strains. Values are Mean \pm SD. *p $<0.05 \mathrm{v} / \mathrm{s}$ L. casei.

3.6 Assessment of therapeutic potential of $L$. casei and $L$. yoghurt in murine giardiasis

Among all the five isolated strains L.yoghurt exhibited better probiotic characteristics hence was employed to assess its therapeutic potential in murine giardiasis.

\subsection{Enumeration of Giardia cysts}

It was observed that the excretion of cysts increased gradually from day 0 onwards and was significantly $(\mathrm{p}<0.05)$ more on day 7 post inoculation (PI). Thereafter, the cyst count started decreasing and mice became Giardia free by day 30 PI. However, oral feeding of $L$. casei or $L$. yoghurt one day after infection significantly $(\mathrm{p}<0.05)$ reduced the cyst excretion from day 3

Am. J. Biomed. Sci. 2010, 2(3), 248-261; doi: 10.5099/aj100300248 @ 2010 by NWPII. All rights reserved. 
onwards in Giardia- L. casei and Giardia - L. yoghurt mice (Group III and IV, Figure 8). Moreover, none of the Giardia infected mice had any other clinical symptoms like diarrhea, weight loss. Interestingly, daily feeding of either $L$. case $i$ or L. yoghurt after Giardia challenge reduced the severity of infection but was unable to reduce its duration. This may be due to the fact that Giardia trophozoites adhered to the microvilli and their establishment. However, after probiotic administration, Giardia infection did not increased significantly. This may either be due to competition for resources [28], bacterial exocellular factors [29-31], or binding ability of the lactobacilli to the intestinal epithelial cells [3233].

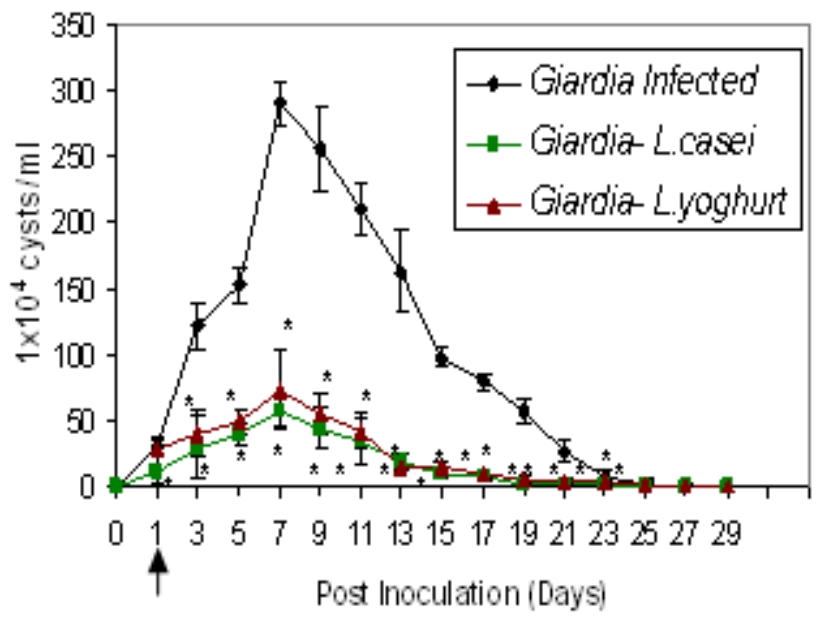

Figure 8: Enumeration of Giardia cysts in faeces of different groups of mice treated with $L$. casei and $L$. yoghurt as the probiotic. Values are Mean $\pm \mathrm{SD}$, *p<0.05 v/s Giardia infected, Probiotic treatment $\uparrow$.

\subsection{Enumeration of lactobacilli in faeces}

Intact intestinal mucosa acts as a barrier to exclude pathogen translocating into intestinal organs and tissues. However, intestinal inflammation due to intestinal disorders could alter the permeability of this barrier, which could lead to invasion of pathogens, foreign antigens and other harmful substances [34]. Therefore, probiotic bacteria that are able to survive gastric conditions and colonize the intestine can be used to treat patients with intestinal disorders. In the present study ability of lactobacilli to persist in gastrointestinal tract was monitored by counting their number in feces of mice. Interestingly, the faecal lactobacilli counts increased significantly $(\mathrm{p}<0.01)$ in Giardia - L. casei and Giardia - L. yoghurt (Group III and IV) compared to Giardia infected mice (Group II, Figure 9). This observation corroborates with the earlier studies carried out by Yuki et al. 2000 (35), Oyetayo et al. (36) and Shukla et al. 2008 (8), suggesting that lactobacilli not only survived the gastrointestinal passage but also adhered effectively to the epithelial lining of animal gut, thus providing a continuous inoculum of specific lactobacilli that may have additive effects.

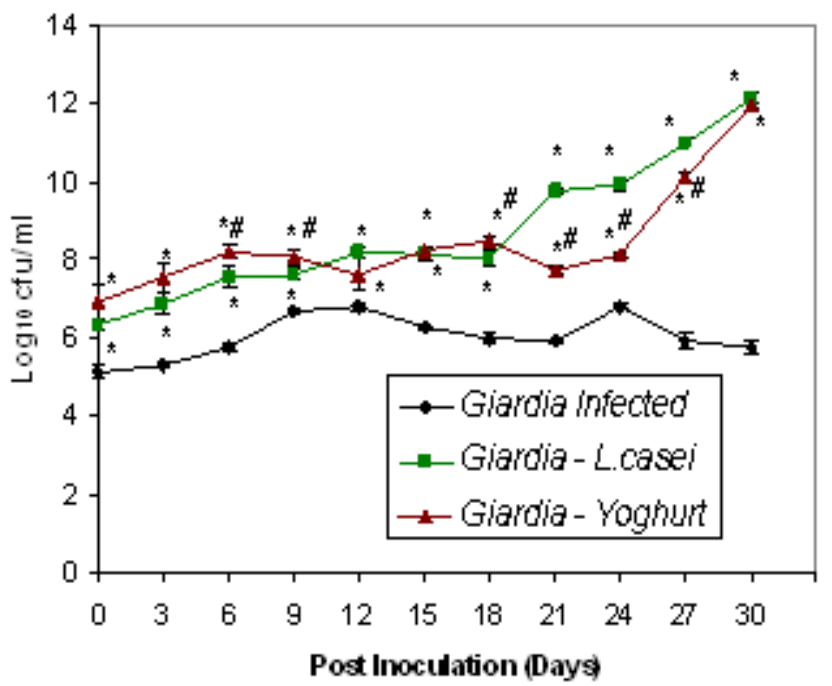

Figure 9: Lactobacilli count $\left(\log _{10} \mathrm{cfu} / \mathrm{ml}\right)$ in faeces of different groups of mice treated with $L$. casei and $L$. yoghurt as the probiotic. Values are Mean $\pm \mathrm{SD}$, *p $<0.001 \mathrm{v} / \mathrm{s}$ Giardia infected group, \#p<0.05 v/s L. casei.

\subsection{Enumeration of Giardia trophozoites}

It was observed that the administration of either L. casei or L. yoghurt significantly ( $<<0.05)$ reduced the trophozoites counts in the gut of Giardia-Probiotic treated mice (Group III and IV) compared to Giardia infected mice (Group II, Figure 10) and is in accordance with Humen et al. 2005 (37) and Shukla et al. 2008 (8). 


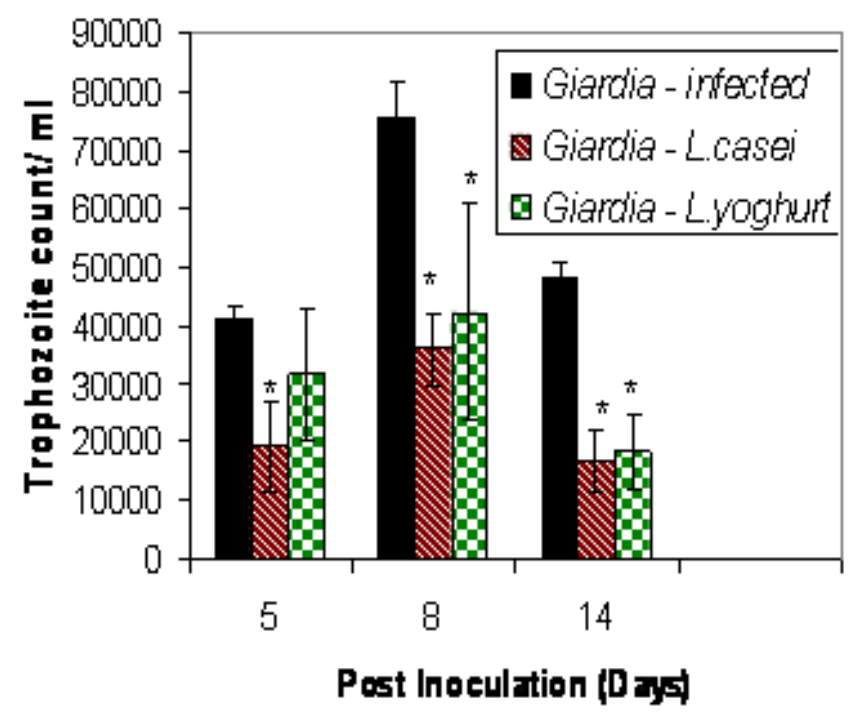

Figure 10: Enumeration of Giardia trophozoites in small intestine of different groups of mice using $L$. casei and L. yoghurt as the probiotic supplement. Values are Mean $\pm \mathrm{SD},{ }^{*} \mathrm{p}<0.05 \mathrm{v} / \mathrm{s}$ Giardia infected.

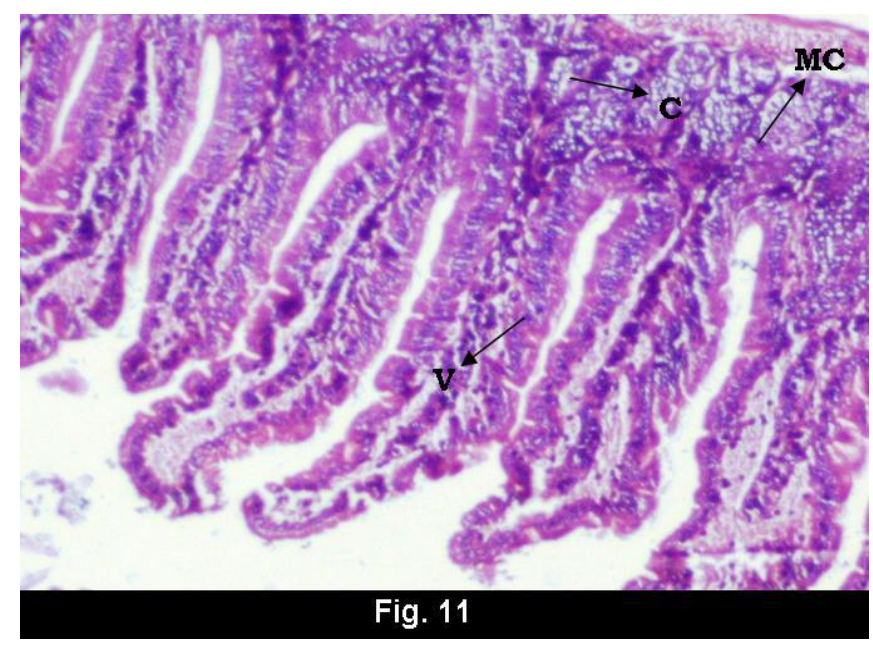

Figure 11: Photomicrograph of the small intestine of Control (Group I) mouse showing a healthy muscle coat (MC), intact mucosal epithelial lining, basal crypts (C) and normal villi (V) (H\&E stain, $100 \mathrm{x}$ ).

\subsection{Histopathological studies}

Histologically, the small intestine of the control (Group I) mice had healthy muscle coat, intact mucosal epithelial lining, basal crypts and normal villi compared to varying degrees of villous atrophy, inflammation, lymphocytic infiltration and lymphocytic hyperplasia in Giardia infected mice (Figure 11 and 12 a, b, c). Interestingly, probiotic supplementation after Am. J. Biomed. Sci. 2010, 2(3), 248-261; doi: 10.5099/aj100300248
Giardia infection reduced the inflammation of the small intestine but the damage was less in Giardia - L. casei mice compared to Giardia - L. yoghurt

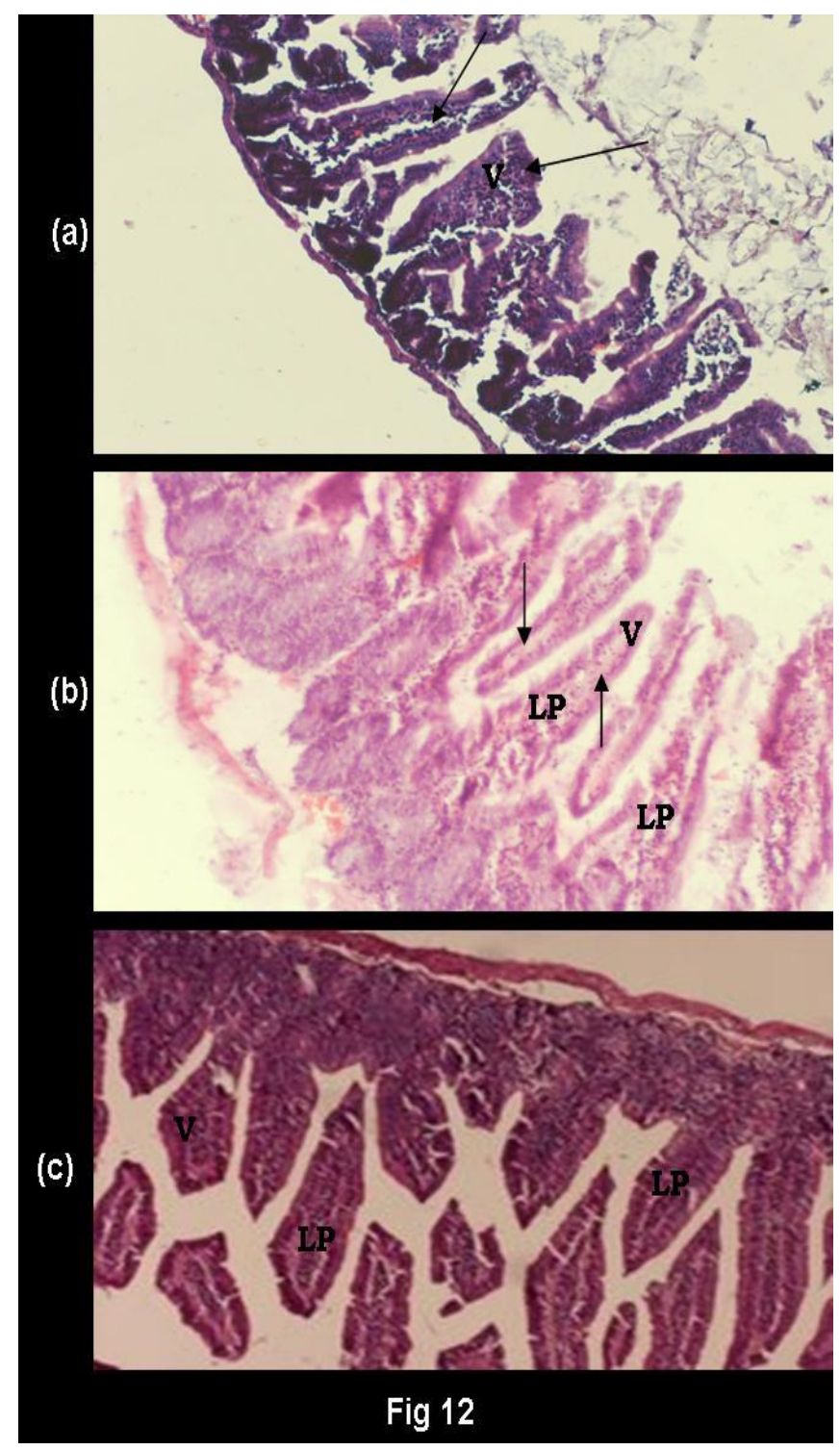

Figure 12: Photomicrograph of the small intestine of Giardia infected (Group II) mouse; a) day 5 showing inflammation of villi (V) along with lymphocytic infilteration in the lamina propria (single arrow)and normal epithelium; b) day 8 showing inflamed and disrupted villi $(\mathrm{V})$ with high number of inflammatory cells in the lamina propria (LP) and intact epithelium ( single arrow); c) day 14 showing damaged microvilli $(\mathrm{V})$, reduced villus height, increased lymphonuclear cell infilteration in lamina propria (LP) and mild ileitis (H\&E stain, 100x).

(C) 2010 by NWPII. All rights reserved. 


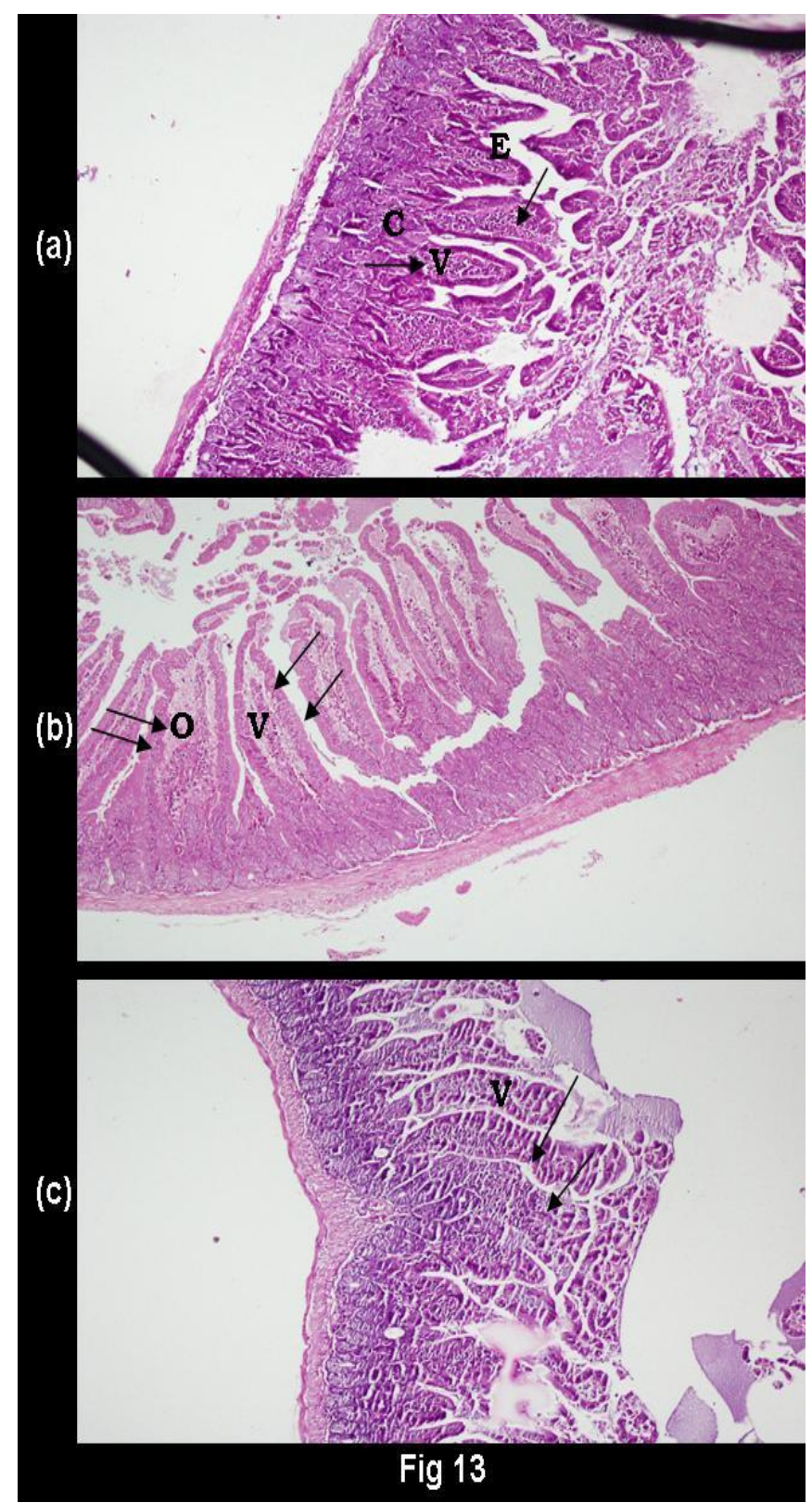

Figure 13: Photomicrograph of the small intestine of Giardia - L. casei ( Group III) mouse; a) day 5 showing mild swelling of villi (V single arrow), cell infilterates devoid of mononuclear histiocytes with abundant plasma cells in lamina propria, healthy epithelium (E) with crypts (C) showing paneth cell hyperplasia, a case of mild plasma cell rich ileitis; b) day 8 showing swollen villi $(\mathrm{V})$ with oedema $(\mathrm{O})$, normal epithelium and brush border of the villi (double arrow) and inflammed villi; c) day 14 showing slightly disrupted villi (V) but normal in height with mild increase of mononuclear cells in lamina propria ( single arrow, H\&E stain, 100x).

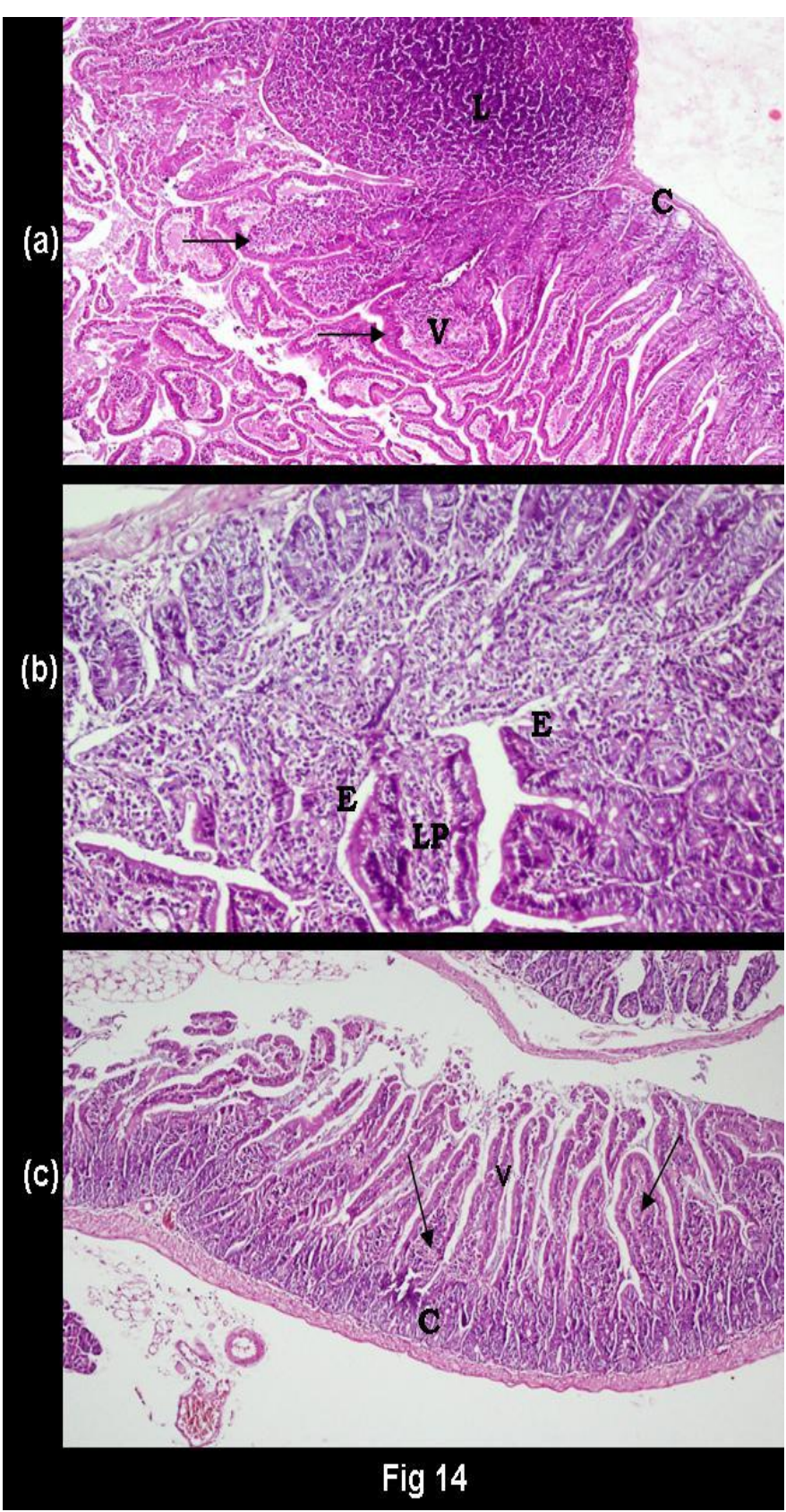

Figure 14: Photomicrograph of the small intestine of Giardia - L. yoghurt ( Group IV) mouse; a) day 5 showing normal crypts (C), hyperplasia of paneth cells, a possibly large lymphoid aggregate ( Peyer's Patch L), bulbous swelling of villi (V) and normal epithelium/ brush border (single arrow); b) day 8 showing disrupted villi due to inflammatory cells in the lamina propria (LP) and eroded epithelium (E); c) day 14 showing normal crypts (C), long villi (V) with less number of inflammatory cells in the lamina propria ( single arrow, $H \& E$ stain, 100x). 
(Figure 13 a, b, c and 14 a, b, c). Initially, the small intestine of Giardia - L. yoghurt (Group IV) mice showed inflamed villi with excess of lymphomononuclear cells in the lamina propria along with fibrinous exudates beneath the epithelium (Figure 14b) while Giardia - L. casei mice (Group III) had more number of plasma cells in the lamina propria, swollen villi and oedema on day 8PI (Figure 13b). Interestingly, villous height increased with mild inflammation in Giardia- $L$. yoghurt mice (Group IV, Figure 14c) but the villous height were normal in Giardia- L. casei mice (Group III) on day 14 PI.

\section{Conclusion}

It has been found from the study that the isolated lactobacilli and yeast strains fulfill the probiotic characteristics and can be used as functional foods for human health. The cholesterol assimilating property of these strains in vitro signifies their role in reducing the risk of coronary heart diseases and warrants further in vivo studies. The L. yoghurt supplementation to Giardia infected mice reduced the severity of Giardia infection.

\section{Acknowledgment}

The authors are grateful to Mr. Bhandari, Senior Technician, Post Graduate Institute of Medical Education and Research, Chandigarh, India, for maintaining the Giardia lamblia (Portland Strain I) culture. Financial assistance provided by Indian Council of Medical Research is highly acknowledged.

\section{References}

1. Tripathi DM; Gupta N.; Lakshmi V.; Saxena KC.; Agarwal AK. Antigiardial and immunostimulatory effect of Piper longum on giardiasis due to Giardia lamblia, Phytother Res, 1999, 13, 561-565.

2. Upcroft P.; Upcroft JA. Drug targets and mechanisms of resistance in the anaerobic protozoa, Clin Microbiol Rev, 2001, 14, 150164.
3. Taherkhani H.; Shariati S.; Abdolahi N.; Roshandel GH. Clinical manifestations of Giardiasis in Iran, Journal of Clinical and Diagnostic Research, 2009, 3, 1416-1418.

4. Ganayni GA.; Attia RA.; Motawea SM. The relation between ABO blood group, HLA typing and giardiasis in children, $J$ Egypt Soc Parasitol, 1994, 24, 407-412.

5. Lemee V.; Zaharia I.; Nevez G.; Rabodonirina M.; Brasseur P.; Ballet JJ .; Favennec L. Metronidazole and albendazole susceptibility of 11 clinical isolates of Giardia duodenalis from France, J Antimicrob Chemother, 2000 46, 819-821.

6. Gardner TB.; Hill DR. Treatment of giardiasis, Clin Microbiol Rev, 2001, 14(1), 114-2.

7. Calzada F.; Meckes M.; Cedillo-Rivera R. Antiamoebic and antigiardial activity of plant flavonoids, Planta Med, 1999, 65: 78-80.

8. Shukla G.; Devi P.; Sehgal R. Effect of Lactobacillus casei as a probiotic on modulation of giardiasis, Dig Dis Sci, 2008, 53, 2671-2679.

9. Marteau P.; Cuillerier E.; Meance S.; Gerhardt MF.; Myara A.; Bouvier M.; Bouley C.; Tondu F.; Bommelaer G .; Grimaud JC. Bifidobacterium animalis strain DN-173 010 shortens the colonic transit time in healthy women: a double-blind, randomized, controlled study, Aliment Pharmacol Ther, 2002, 16, 587-593.

10. Kim HJ.;Shin HS.; Ha WK.; Yang IH.; Lee SW. Characterization of lactic bacterial strains isolated from raw milk, Asian-Aust J Anim Sci, 2006 19,131-136.

11. Lewis SJ.; Freedman AR. Review article: the use of biotherapeutic agents in the prevention and treatment of gastrointestinal disease, Aliment Pharmacol Ther, 1998, 12, 807-822.

12. Gilliland SE; Staley TE; Bush LJ. The importance of bile tolerance of Lactobacillus acidophilus used as a dietary adjunct, J Dairy Sci, 1984, 67, 3045-3051.

13. Nowroozi J.; Mirzaii M.; Norouzi M. Study of Lactobacillus as probiotic bacteria, Iranian $J$ Publ Health, 2004, 33(2), 1-7.

14. Liong MT.; Shah NP. Acid and bile tolerance and cholesterol removability of lactobacilli strains, J Dairy Sci, 2005, 88:55-66. 
15. Zlatkis A.; Zak B.; Boyle AJ. A new method for the direct determination of serum cholesterol, J Lab Clin Med, 1953, 41, 486492.

16. Tiwari R.P.; G.S. Hoondal and R.Tewari. Laboratory Techniques in Microbiology and Biotechnology, Abhishek Publication, 2004.

17. Singer SM.; Nash TE. The role of normal flora in Giardia lamblia infections in mice, J Infect Dis, 2000, 181, 1520-1522.

18. Glodin BR. Health benefits of probiotics, $\mathrm{Br} J$ Nutr, 1998, 80(suppl.2), 5203-5207.

19. Kaur P.; Bhatia A. The recent developments in molecular techniques for the detection of probiotics, Int J Probiotics Prebiotics, 2008, 3, $65-70$.

20. Usman.; Hosono A. Bile tolerance, taurocholate deconjugation, and binding of cholesterol by Lactobacillus gasseri strains, $J$ Dairy Sci,1999, 82, 243-248.

21. Dunne C.; O’Mahony L.; Murphy L.; Thornton G.; Morrissey D.; O’Halloran S.; Feeney M.; Flynn S.; Fitzgerald G.; Daly C.; Kiely B.; O'Sullivan G.; Shanahan F .; Collins K. In vitro selection criteria for probiotic bacteria of human origin: correlation with in vivo findings, Am J Clin Nutr, 2001, 73, 386S$392 \mathrm{~S}$.

22. Kheadr EE. Impact of acid and oxgall on antibiotic susceptibility of probiotic lactobacilli, Afr J Agri Res, 2006, 1(5), 172181.

23. Ritus N.; Sole M.; Francis A.; Loren JG. Buffering capacity and membrane $\mathrm{H}^{+}$ conductance of lactic acid bacteria, FEMS Microbiol Lett, 1994, 120, 291-296.

24. Berada N.; Lemeland JF.; Laroch G.; Thouvenot P.; Piala M. Bifidobacterium from fermented milks: Survival during gastric transit, J Dairy Sci,1991, 74, 409- 413.

25. Anderson JW.; Gilliland SE. Effect of fermented milk (yoghurt) containing Lactobacillus acidophilus L1 on serum cholesterol in hypercholesterolemic humans, $J$ Am Coll Nutr, 1999, 18, 43- 50.

26. Sanders ME. Considerations for use of probiotic bacteria to modulate human health, $J$ Nutr, 2000, 30, 384S-390S.
27. Pereira DIA ; Gibson GR. Cholesterol assimilation by lactic acid bacteria and biofidobacteria isolated from the human gut, Appl Environ Microbiol, 2002, 68(9), 46894693.

28. Cebra JJ. Influences of microbiota on intestinal immune system development., Am J Clin Nutr, 1999, 69: 1046S-1051S.

29. Bernet-Camard MF.; Lievin V.; Brassart D.; Neeser JR.; Servin AL.; Hudault S. The human Lactobacillus acidophilus strain LA1 secretes a nonbacteriocin antibacterial substance(s) active in vitro and in vivo, Appl Environ Microbiol, 1997, 63, 2747-2753.

30. Coconnier MH.; Lievin V.; Hemery E .; Servin AL. Antagonistic activity against Helicobacter infection in vitro and in vivo by the human Lactobacillus acidophilus strain LB, Appl Environ Microbiol, 1998, 64, 45734580.

31. Le Moal V.; Amsellem R.; Servin AL.; Coconnier $\mathrm{MH}$. Lactobacillus acidophilus (strain LB) from the resident adult human gastrointestinal microflora exerts activity against brush border damage promoted by a diarrhoeagenic Escherichia coli in human enterocyte-like cells, Gut, 2002, 50, 803-811.

32. Bernet MF.; Brassart D.; Neeser JR .; Servin AL. Lactobacillus acidophilus LA 1 binds to cultured human intestinal cell lines and inhibits cell attachment and cell invasion by enterovirulent bacteria, Gut, 1994, 35, 483-489.

33. Bibiloni R.; Pérez PF.; De Antoni GL. Will a high adhering capacity in a probiotic strain guarantee exclusion of pathogens from intestinal epithelia? Anaerobe, 1999, 5,519524.

34. Salminen S. ; Bouley C. ; Boutron-Ruault MC et al. Functional food science and gastrointestinal physiology and function, $\mathrm{Br} J$ Nutr, 1998, 80, S147-171.

35. Yuki N.; Shimazaki T.; Kushiro A.; Watanabe K.; Uchida K.; Yuyama T ; Morotomi M. Colonization of the stratified squamous epithelium of the nonsecreting area of horse stomach by lactobacilli, Appl Env Microbio, 2000, 66, 5030-5034.

36. Oyetayo VO.; Adetuyi FC.; Akinyosoye FA. Safety and protective effect of Lactobacillus 
acidophilus and Lactobacillus casei used as probiotic agent in vivo, Afr J Biotechnol, 2003, 2(11), 448-452.

37. Humen MA.; De. Antoni GL.; Benyacoub J.; Costas MB.; Cardozo MI.; Kozubsky L.; Saudan K.; Doenzli-Bruand A.; Blum S.;
Schiffrin EJ.; Perez PF. Lactobacillus johnsonii La1 antagonizes Giardia intestinalis in vivo, Infect Immun, 2005,7,1265-1269. 